Proceedings

\title{
Axonometry: The Grip of Thought on Space -A Short Survey on the Relation between the Act of Planning and a Visionary Visualization Technique ${ }^{\dagger}$
}

\begin{abstract}
Fabiano Cocozza
Via Manzotti 23, 20158 Milan, Italy; fabiano.cocozza@gmail.com; Tel.: +39-328-426-2241

+ Presented at the International and Interdisciplinary Conference IMMAGINI? Image and Imagination between Representation, Communication, Education and Psychology, Brixen, Italy, 27-28 November 2017.

Published: 16 November 2017

Abstract: Among the tools available to designers to illustrate their thoughts, the most meaningful is axonometry. As testified by its use throughout art history, axonometry was by far preferred for technical explanations, as a three-dimensional proof of functioning and buildability. The relation between axonometric drawings and design thinking is so strong that the former has become the epitome of the latter. The purpose of this paper is to investigate the key factors underlying this relation and the reasons why axonometry embodies the project aesthetics. After a brief overview of its history, the practical, scientific and visionary features of axonometry will be outlined.
\end{abstract}

Keywords: history of axonometric drawing; drawing as a tool for design; visual representation; descriptive geometry; history of architecture; history of cartography

\section{Introduction}

Among the tools available to designers to illustrate their thoughts, the most meaningful-the most widely used and paradigmatic - is axonometry. Sketches drawn to take note or to explain an idea are often axonometric views. Drawings provided in assembly instructions-for example, those used for Ikea furniture, Lego bricks and in most manuals for industrial products-are exploded axonometric projections (Figure 1). The relation between axonometric drawings and design thinking is so strong that the former has become the epitome of the latter.

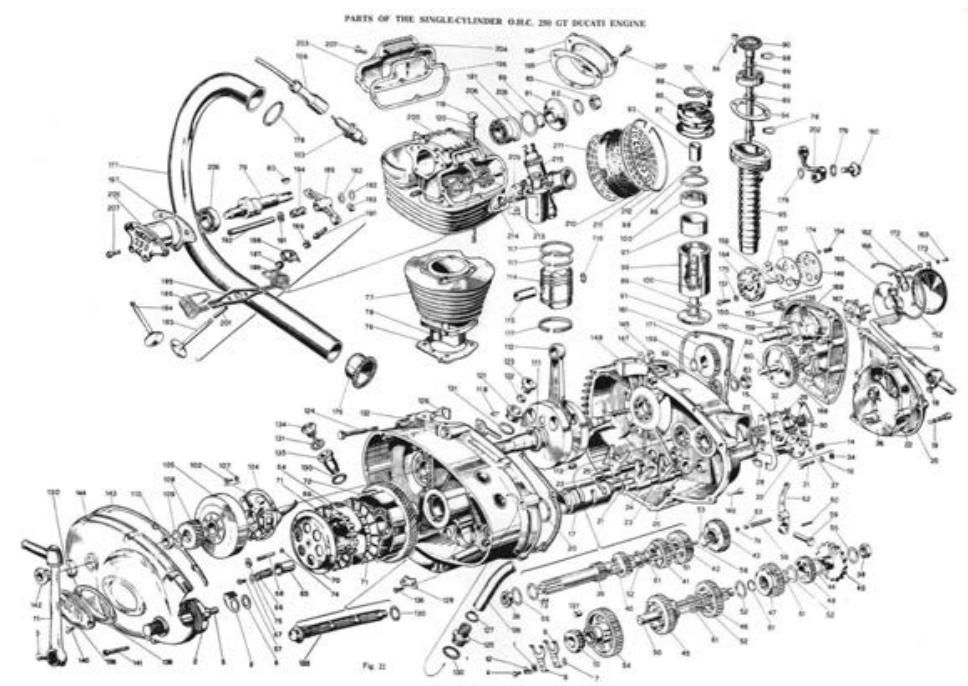

Figure 1. Ducati 250 GT Engine, 1966. 
The purpose of this paper is to investigate the key factors underlying this relation and the reasons why axonometry embodies the project aesthetics. After a brief overview of its history up until today, the practical, scientific and visionary features of axonometry will be outlined.

Even though the word "axonometry" does not appear in the English dictionary, it is widely used in the English translations of the German and Italian literature, where it is preferred to expressions such as "axonometric projection" or "axonometric view". In accordance with this convention, the term "axonometry" will be used to refer to all variations of parallel projections (orthographic, isometric, dimetric, trimetric, rectangular, oblique, cavalier, military, cabinet), and in opposition to "perspective", or central projection. The term "axonometry" shall be used to indicate both the actual picture and the method of representation, i.e., the idea behind it.

\section{Convenience}

The fundamental purpose of every image is to depict a three-dimensional subject-an object or a space - on a surface with only two dimensions-i.e., paper or screen. "It is the essence of a picture that it is two-dimensional, but attempts to represent three dimensions ... (Pictures) are all attempts to solve the same problems, to which a perfect solution is impossible. The imperfect solutions are infinite, however. Each attempt has its own virtues and drawbacks" [1] (Hockney \& G., p. 20).

Axonometry deals with the issue by resorting to geometrical means. In axonometric drawings, three different faces of an object are combined through mathematical calculations and represented on paper, on a flat surface. The faces are reproduced faithfully in accordance with their arrangement in space. Unlike orthogonal projections, in which only one face of a subject is depicted at a time, in parallel projections, front, side and plan meet together on one surface and became equally visible from a single point of view with an impression of depth. The final result resembles the natural perception: the subject remains recognizable even though it is slightly distorted.

Starting from the measurements of the drawing and working backwards through the mathematical calculation, an axonometry allows to obtain the physical dimensions of the represented subject. Therefore, this technique is a practical means to communicate the shape and the dimension of a subject, which is fundamental for the production of an object or for the metric survey of a space.

Axonometry combines the geometrical convenience of parallel projections and the appearance of a painting. Practical, accurate and easy to understand, it is inherently-mathematically-connected to the physical world.

\section{Appearance}

The appearance of a subject in an axonometric drawing is similar real life. Although it looks familiar, it is not the same as the real image in that there is something discordant, anomalous, unnatural to it.

The proportions of the subject are correct, but the "posture" has something unusual. In real life as in perspective representation, the observer scans the scene from a position within the scene, and near objects look bigger than distant ones.

Conversely, the point of view in axonometry is outside the scene, it is "abstract". All objects in the picture have the same proportions and are equally distant from the viewer. Everything inside the drawing is equally visible, near and far objects have the same scale, the same value. The axonometric space conveys depth but not distance.

By removing the viewer from the scene, axonometry loses the connection with the natural perception but provides a sense of control and superiority. From above, the viewer sees everything at the same time: the whole thing and its details are visible simultaneously in a single image.

This characteristic becomes more remarkable as the size of the subject increases. While dominating a small object in a single glance is a common perception, the full view of a wide space in one look is empowering. Axonometry places the observer in a position that is otherwise impossible in nature, in a supernatural point of view. 


\section{Cartography}

An observation point from above is quite useful for a cartographer. Cartographers used parallel projections extensively because of their ability to depict both the details and the whole view. One of the first examples is the Map of Venice by Jacopo De Barbari (1500). Probably influenced by the Chinese handscrolls brought to the city by his fellow trading citizens, this huge woodcut $(1.5 \times 3$ meters) is an incredibly meticulous and detailed aerial view of the city. After this accomplishment, De Barbari moved to Germany, where the cartographic axonometric technique (Vogelschaukarten) was well received and developed long afterwards, reaching exceptional level in the 19th century.

Indeed, it was a German cartographer-Hermann Bollmann - who produced probably the most popular axonometric map in history: the Map of New York for the 1964 New York World's Fair, where it was sold at information and tourist kiosks. Trained in military perspective during his service in the Second World War, Bollmann "confronted modernity's most demanding urban landscape: Manhattan Island. Using 67,000 photographs ... he created a hand-drawn map image that captures precisely the soaring quality of New York's skyline, while rendering streets and buildings with remarkable accuracy" [2] (Cosgrove, p. 156) (Figure 2).

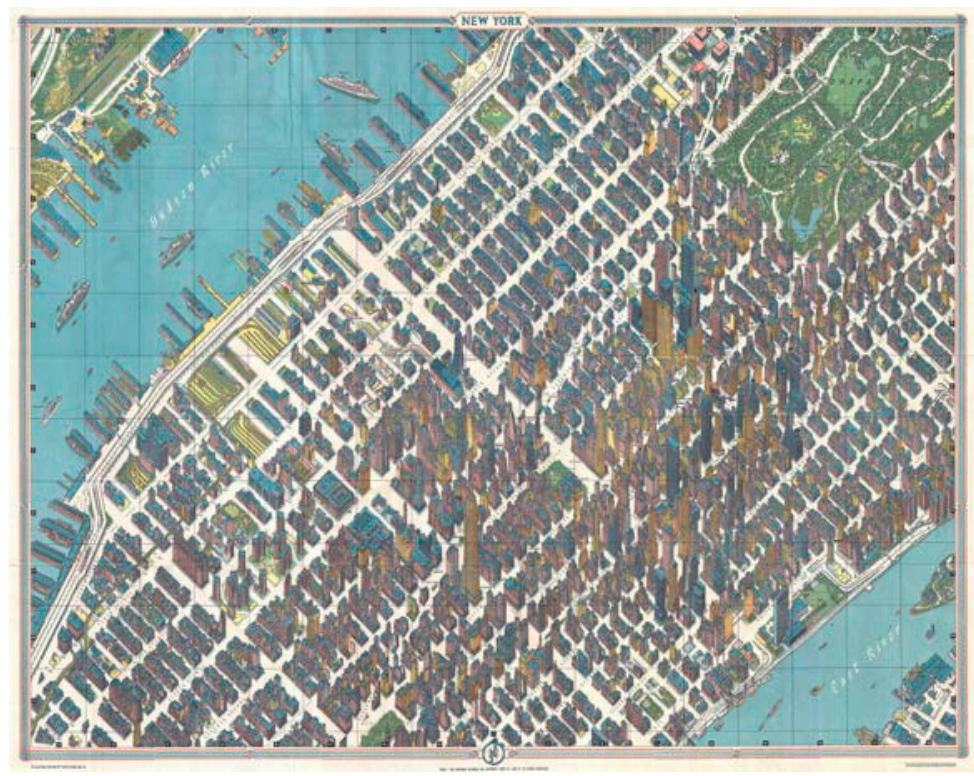

Figure 2. Hermann Bollmann, New York Map, 1963.

\section{Sketching}

Drawing is the project medium. The first way to make an idea tangible is to sketch it on paper, as the sketch will conveniently store and convey the idea. But this is not the only reason. Through the act of drawing, the idea takes shape and is made plain both for a potential audience and for the thinker himself. During the design process, thinking and drawing happen simultaneously, merging in a single activity. In a continuous loop, the sketch and the idea-mind, hand and eyes-send feedback to each other. Sketching brings new ideas, which bring about more sketches: design thinking evolves and is clarified by drawing.

Carlo Scarpa (1906-1978) based his architectural production on a proliferation of drawings-one of his archives (Centro Carlo Scarpa at the State Archive of Treviso [3]) includes a collection of over 30,000 samples. "I want to see things; I trust only this. I want to see, this is why I make drawings. I can see an image only if I draw it" [4] (Carlo Scarpa quoted in Gellner \& M., p. 38). The majority of Scarpa's sketches are or contain axonometric drawings (Figure 3). The architect used axonometry as technique to "see" his ideas. In the urgency to clarify the construction details to the workers on the building site, parallel projections were even roughly drafted by hand over the neat final drawings-as the ones for the Castelvecchio Museum (1956-1964) (stored in another archive, the Museum Archive in Verona [5]). At that time, construction workers (with poor or no formal education at all) probably 
struggled to understand complex orthogonal sections, but immediately grasped the much more userfriendly axonometric views. In the drawing field, axonometry is a medium for masses.

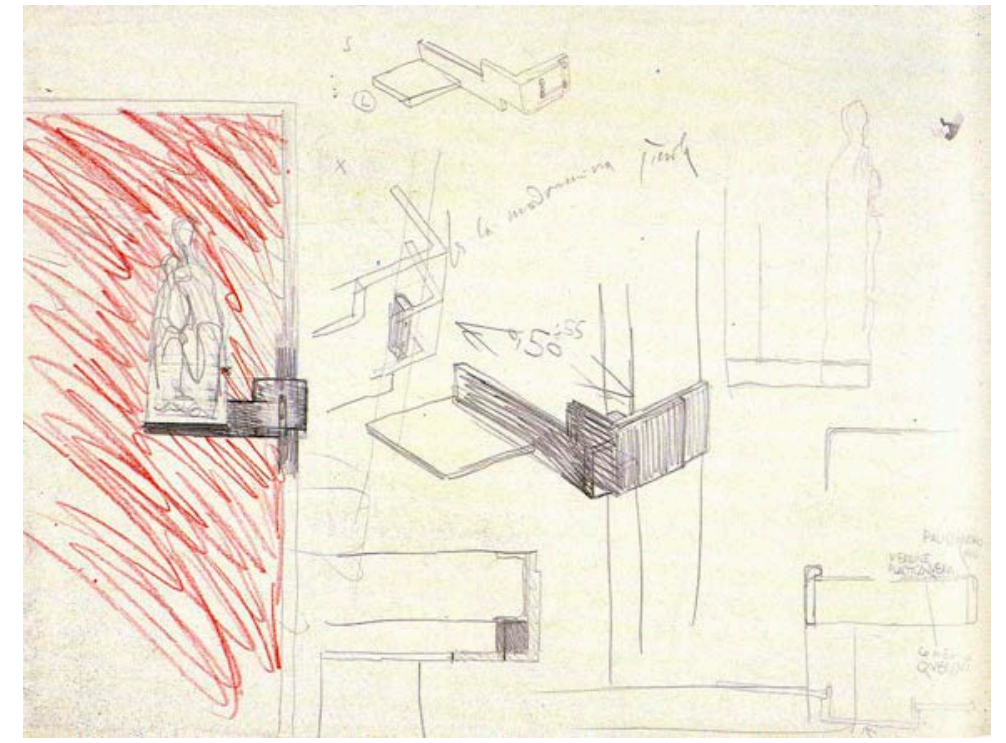

Figure 3. Carlo Scarpa, Sketch for Castelvecchio, 1962-1964.

The choice of parallel projections among the various other methods of representation cannot be limited to its approachability or handiness. Even during the Renaissance, while perspective was booming, axonometry was by far preferred for technical explanations.

In the opening of his "Oblique Drawing: A History of Anti-Perspective", when commenting on Leonardo da Vinci's drawings, Massimo Scolari (1943)-architect, scholar and extraordinary axonometric practitioner-clearly stated that: "The appearance of parallel projection in Leonardo's work obviously cannot be explained by his uncertain preparation in other techniques or by the quick execution of sketches. Rather, it seems he chose it because it was better suited to representing the actual space of an object rather than an object in space." [6] (Scolari, p. 1) (Figure 4). Scolari pushed the concept even further by maintaining that axonometry was used as a sort of demonstration of the feasibility of an invention: "Whatever the ease may be, the drawings of Leonardo, Conrad Kyeser, and Taccola go beyond pure representation due to the accentuation of mechanical functional elements ... They use the very old tradition [of parallel projections] in a new way-as a three-dimensional proof of functioning and buildability ... This is a result that could not be achieved with perspective" [7] (Scolari, p. 3).

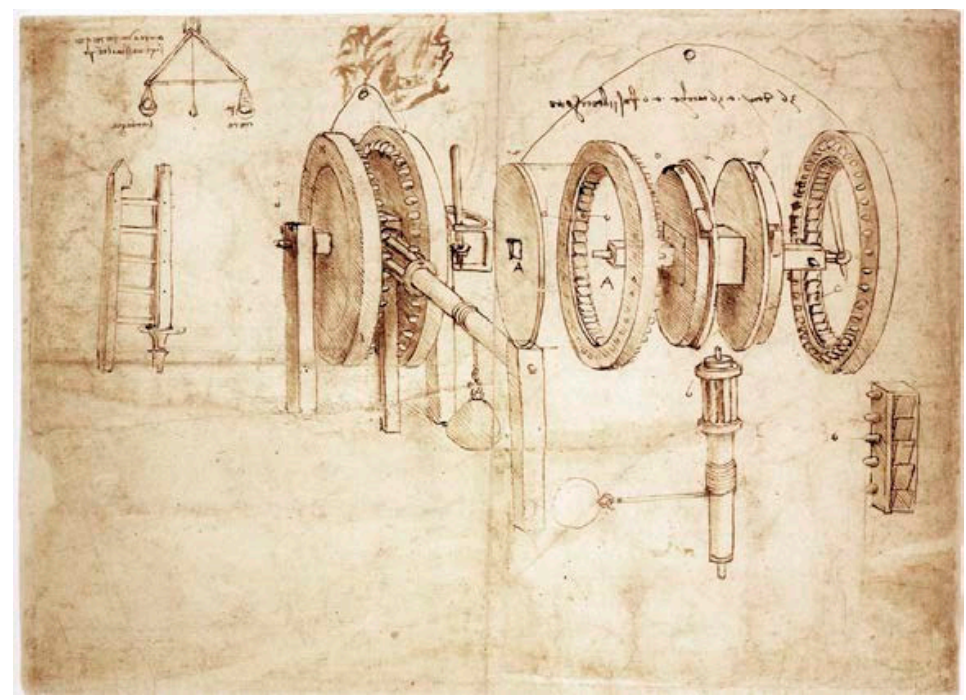

Figure 4. Leonardo da Vinci, Codex Atlanticus, 1478-1519. 


\section{Origins}

The convenience of axonometry is also confirmed by its ancient history. While its place and date of origin cannot be established with certainty, the first representations depicting depth on a flat surface can be considered as proto-parallel projections.

In the history of Western art, clear examples of parallel projections can be found in Roman frescoes - which achieved marvelous tromp-l'oeil effects in Pompeiian villas, -in Medieval art-e.g., Giotto in the Scrovegni Chapel [8] (Hockney \& G, p. 88), - and in the Renaissance, when perspective became the technique of choice used by artists, while axonometry fulfilled technical demands.

The Saint Lawrence grill from the mosaics in the Mausoleum of Galla Placidia in Ravenna $(425-450)$ is not the earliest example, but it does provide a perfect clarification. The grill shows, thanks to its structure, the axonometric grid on which the picture is based. In the same vault, on the left, the open cabinet that hosts the books of the Gospels is a perfect case of "cabinet projection" (Figure 5).

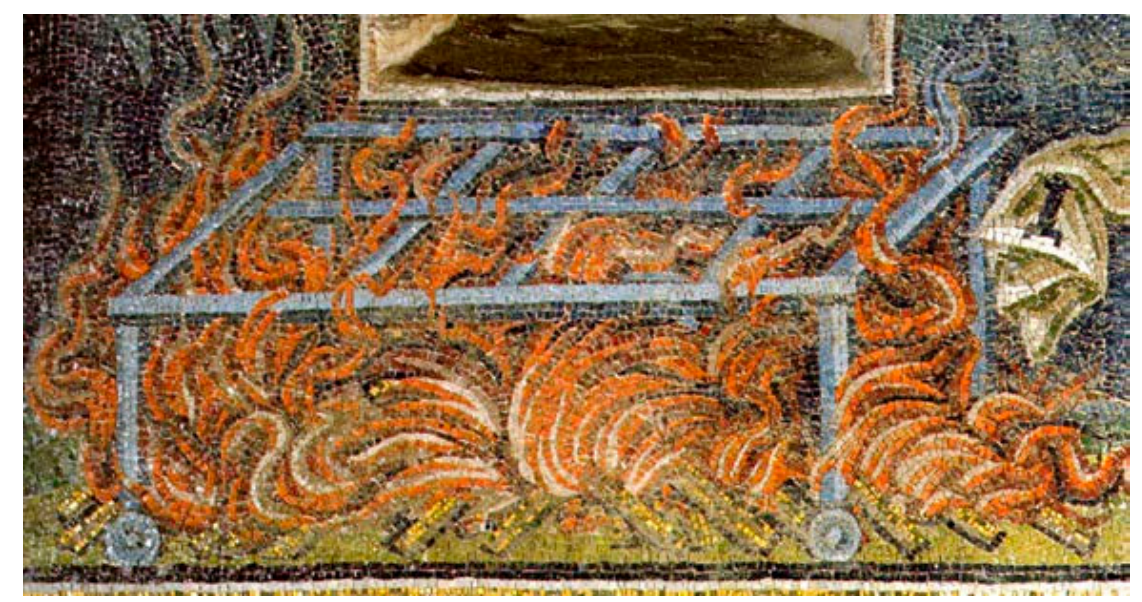

Figure 5. Mausoleum of Galla Placidia, southern lunette detail, 425-450.

In the history of Eastern art, the origins of axonometry could even date back to earlier times, but are equally untraceable. "Chinese painting does not have a fixed viewpoint, it is based on a moving focus" [9] (Hockney \& G, p. 89). Traditional Chinese landscape paintings were made on long handscrolls. The handscrolls were shown mimicking a journey through the painted landscape, rolling and unrolling a portion at a time. Therefore, a single vanishing point - as in perspective-would have been impractical. The viewer could not see the entire picture at once, and the length of the handscroll would cause the figures at the sides to appear too distorted. The painting was "a space which implied more space beyond the picture frame ... (The artist) practiced the principle of the moving focus, by which the eye could wander while the spectator also wandered in imagination through the landscape" [10] (Rowley, pp. 61-63).

Landscapists were like movie directors, and the handscrolls were their documentaries. In 1698 renowned painter Wang Hui was commissioned to record the Kangxi emperor journey over southern China. Wang produced a series of twelve oversize handscrolls, each measuring from twelve to twenty-four meters in length, basing his design only on reports, maps and woodblock prints. With the 'moving focus' principle, he collected a profusion of detailed scenes in a monumental landscape format. The result is astonishing: "By transforming each illustrative unit into a full-length landscape, Wang attained a new grandeur of scale that significantly altered the character of his narrative ... to permit a comprehensive cataloguing of styles, architectural and landscape motifs, professions, and figure types. The painting ... depicts not only the paradigmatic actions of the ruler but also the full route, modes of travel, topography, rural and urban scenery, and the everyday activities of his subjects" [11] (Hearn, p. 178) (Figure 6). 


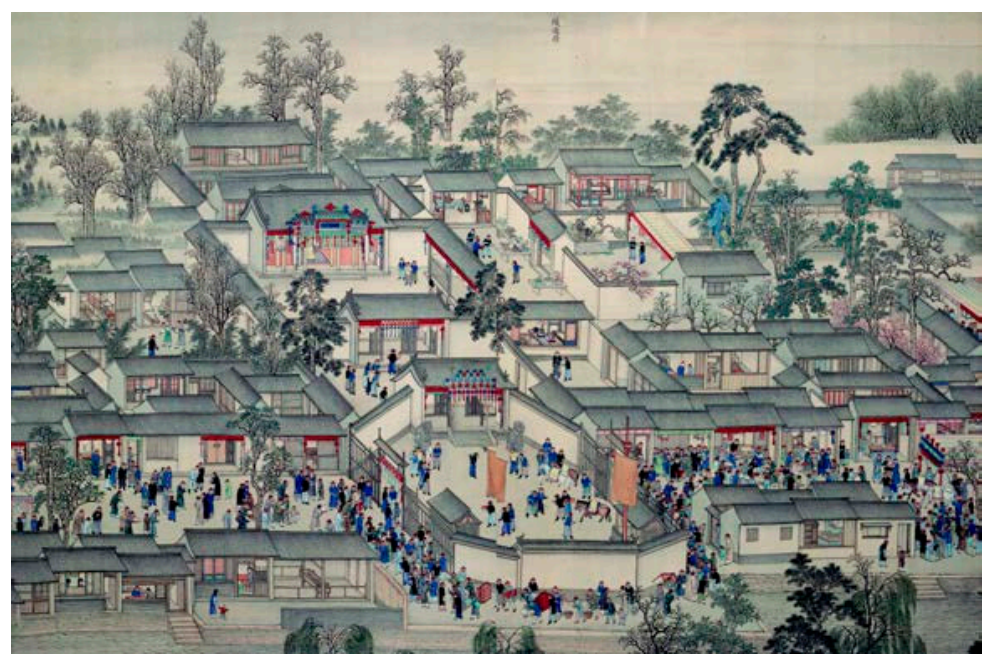

Figure 6. Wang Hui, Kangxi Emperor s Southern Inspection Tour, Scroll Seven, 1689 detail.

\section{Antagonism}

The role of perspective in the Western culture has been extensively debated [12]. With the introduction of central projection (Leon Battista Alberti, "De Pictura", 1434-1436), axonometry lost its lead. From the Renaissance onwards, the monocular vision of perspective dominated the Western art production.

While perspective gives a more realistic look, it freezes the view in an unnaturally single point of observation. The axonometric view is less realistic but engages the observer to wander inside the picture. Even if the point of view is outside the image, the observer's mind wanders inside the scene. "We have already mentioned the Medusa-like quality of perspective: perspective is, in a way of speaking, like the Gorgon's head which petrifies the viewer, while axonometry is related to the flying horse Pegasus which sprang from Medusa's blood" [13] (Bois, p. 57).

At least at the beginning, Leon Battista Alberti's teachings limited the spreading of perspective in the technical field. In "De re aedifcatoria" (1450), Alberti warned architects against the flattery of perspective that would only produce false appearances in architectural drawings; thus it was a tool for painters only. Alberti suggested that only orthogonal projections and physical models were trustworthy [14] (Bois, p. 46).

Parallel projections were then confined to a limited field, i.e., military engineering, where a specific axonometric typology was invented on purpose, namely the military projection. Manuals on the development of city fortifications (Girolamo Maggi and Giacomo Fusto Castriotto, "Della fortificazione delle città", 1564; Giovan Battista Belluzzi, "Nuova inventione di fabbricar fortezze", 1598) explained the reasons why axonometry was to be preferred over perspective: "we [the soldiers] need to see the thing whole, distinct, clear; one can find the truth precisely with compasses ... (In war) one single view does not serve, since the whole has to be shown" [15] (Giovanni Battista Belluzzi, quoted in Scolari p. 9).

\section{Descriptive Geometry}

After three centuries in the shadows, axonometry began flourishing again in 18th century, in the Age of Enlightenment, when Parallel Projections were codified as they are known today. Besides its intuitive origins, axonometry became a clear production of the intellect: this technique was developed and codified to serve as a tool for the scientific look upon nature. Since the publication of "Geometrie descriptive" by Gaspard Monge in 1799-printed posthumously to protect what was considered a military secret, - axonometry and perspective became means for specific, well-defined purposes. Perspective governed appearance, with the goal of tricking the eye of the viewer and make him believe to be part of the scene. Axonometry worked on behalf of reality, to convey a scientific measure of space, to clarify the mind of the viewer, showing things as they are, not as they appears. 
In his speech before the Cambridge Philosophical Society ("On Isometrical perspective", 1822), William Farish officially presented axonometry as the best method for designing and drawing new machinery. Although the technique was already known, Farish was the first to provide rules for isometric projection, explaining the advantages of using only one scale for all three dimensions of space, not only for industrial drawings but in all the scientific fields (Figure 7).

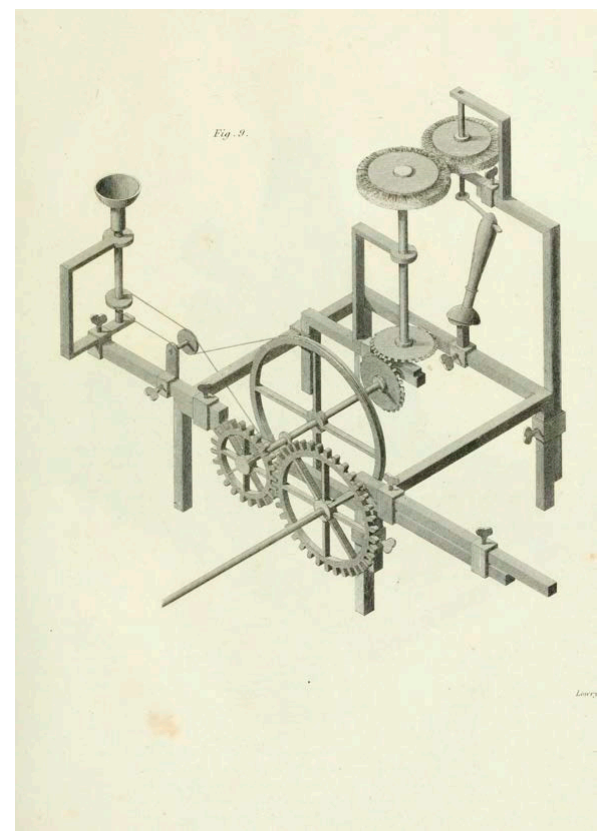

(a)

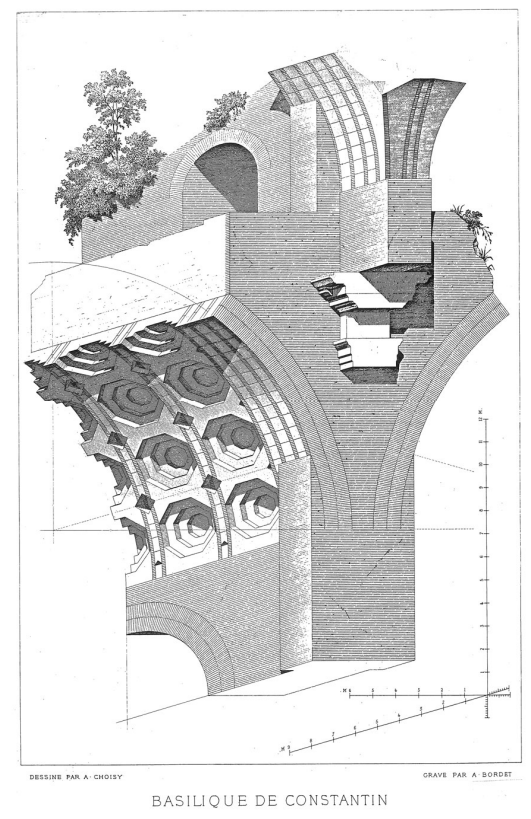

(b)

Figure 7. (a) William Farish, Optimal-grinding engine model, 1822; (b) Auguste Choisy, Planche IIIBasilique de Constantin, from “L'Art de Bâtir chez le Romains”, 1873.

Although Farish's promotion, isometric drawing struggled to be adopted outside the mechanical engineering domain, at least until the time of Auguste Choisy. Since his "L'Art de Bâtir chez le Romains" (1873), Choisy understood the importance of isometric projections in the study of the built environment. He stated clearly the reason of his choice: "ces représentations conventionnelles on été préferéss aux perspectives ordinaires comme se prêtant plus commodément aux mesures" [16] (Choisy). Another proof of the axonometry convenience.

\section{Avant-Gardism}

For long time axonometry role was confined in technical drawing. The art movements of the 1920 's brought it back in the arts field.

It was thanks to the works of two painters, Theo van Doesburg and Cornelis van Eesteren, that Architects rediscovered parallel projections. The De Stijl exhibition held in Paris in 1923 caused general sensation, as it marked the birth of "the modern revival of axonometry" [17] (Bois, p. 42). Meanwhile in Russia, artist El Lissitzky combined the use of axonometry in his paintings known as Proun ("project for the affirmation of the new") with the theoretical essay "A. and Pangeometry" in which he traced the changing concepts of space in the course of history. The text was seminal and his publication in Germany (1925) strongly influenced the theory of the Bauhaus (Figure 8).

De Stijl, Constructivism and Bauhaus pursued the reunion of art and technology, and parallel projections were the perfect means to promote the vision of a neat and harmonious future. Since then, axonometry became the aesthetics of the avant-garde, especially in architecture, where it was employed without distinctions by Modernists, Post-Modernists, De-Constructivists and Radicals. 


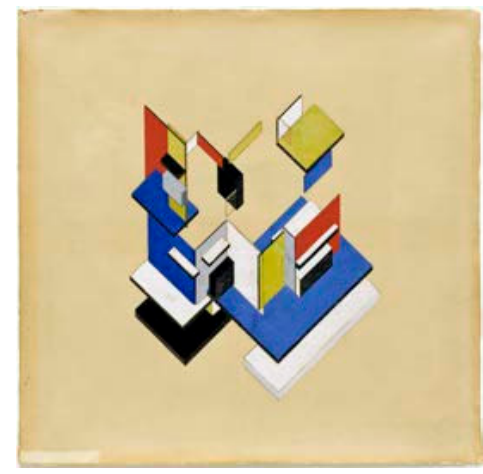

(a)

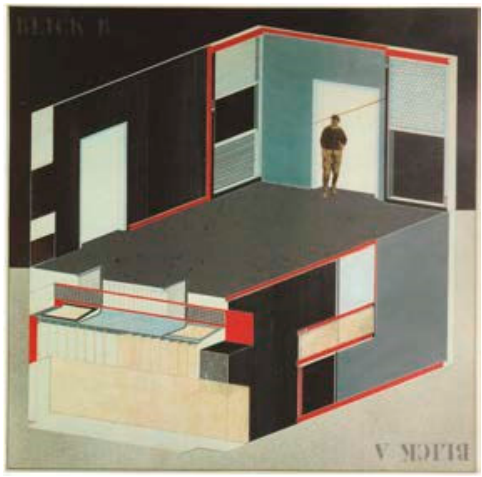

(b)

Figure 8. (a) Theo van Doesburg and Cornelis van Eesteren, Contra-Construction Project, 1923; (b) El Lissitzky, Cabinet of Abstraction, 1927.

Parallel projections are impeccably fit to represent both the idea of a mechanical space and the disconnection from the existing tradition, to trace the vision of an optimistic functional world to come. Axonometric views were the consistent choice for an architecture intended as a machine (of the "First Machine Age" according to Reyner Banham): obtained by calculation, they were used for the mechanical drawings of industrial production, and paired the strive for neatness and order with an un-human look.

\section{Neo-Avant-Gardism}

The influence of the 20th century avant-gardes lasted for long: the architecture movements of the late 1960s and early 1970s established their work on those ideological and aesthetic premises. Modernism grew with a mixture of Suprematism and Surrealism [18] (Frampton, pp. 311-312).

The "Deconstructivist Architecture" exhibition, organized by Philip Johnson and Mark Wigley at the New York Museum of Modern Art (1988), featured works by the most prominent contemporary architects-Frank Gehry, Daniel Libeskind, Rem Koolhaas, Peter Eisenman, Zaha Hadid, Coop Himmelblau, and Bernard Tschumi. The exhibition catalogue crowned axonometry as the visualizing technique of choice, both for its characteristics and as a clear reference to the previous avant-gardes.

In "The City of the Captive Globe Project" (1972), Rem Koolhaas joined two models of parallel projection, i.e., the Constructivist drawings and the cartography tradition (Figure 9).

With a witty allusion to Hermann Bollmann's New York city map, Koolhaas's drawing celebrates Manhattan's "sculpture of congestion," as he wrote in his seminal "Delirious New York" in 1978. In the relentless grid of Manhattan, the architect composes different functional programs, breeding philosophies and art movements previously thought of as incompatible. El Lissitzky's Lenin's Stand, Le Corbusier's Plan Voisin, Salvador Dali's Archeological Reminiscences of Millet's Angelus to name a few: each block is a city in itself. "Koolhaas's metaphor proposes an urban model in which unity accommodates heterogeneity" [19] (Riley, p. 122). Once again, the impartial composition of different scenes is made possible only with parallel projections, only with a view from an infinite point.

The introduction of computer-aided design caused the demise of "paper architects". Since their arrival in the late 1980 's, digital perspective images slowly but effectively came to dominate the scene of architectural representation, putting the use of parallel projections on hold for decades. 


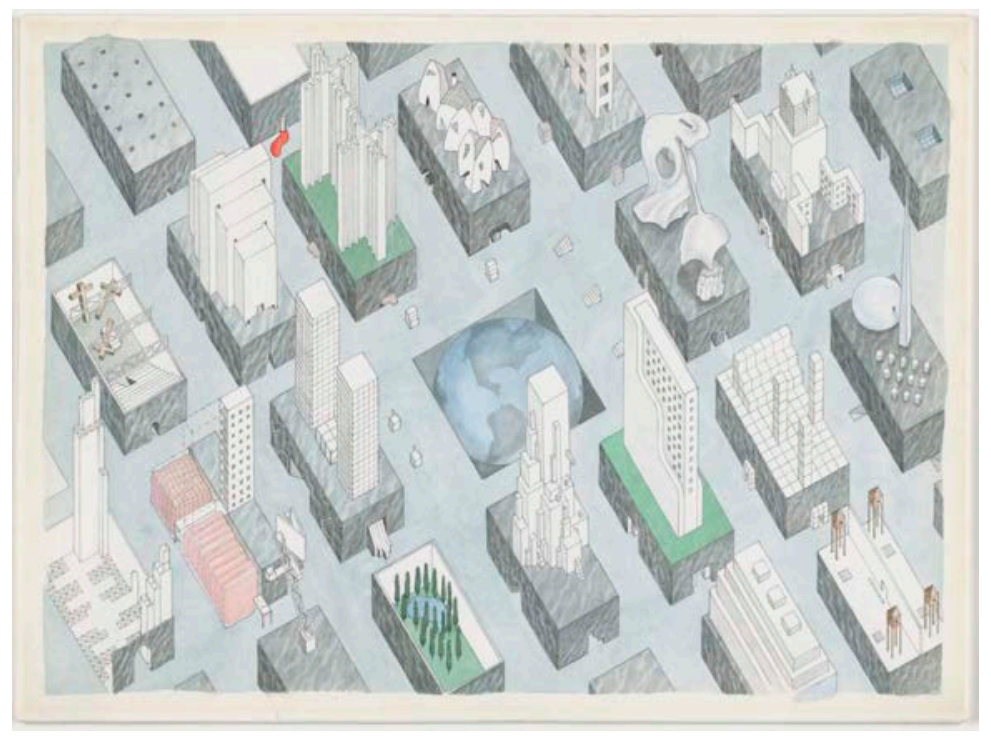

Figure 9. Rem Koolhaas, The City of the Captive Globe Project, 1972.

\section{New Wave}

Nowadays, Bjarke Ingels is often referred to as a valuable successor of Koolhaas, both for his diagrammatic architecture and for his effective communication. Ingels's architectures are presented with an impressive use of computer-generated images, albeit counterbalanced by explanatory axonometric diagrams, adding up the advances of hyper-realistic perspectives with those of abstract vision. Ingels's diagram aesthetics is so popular (at least among architecture students) that it is the subject of You-Tube tutorials. Ingels not only use diagrams to justify his decisions, but also to guide his design: the final building reflects its generative diagram, and becomes a diagram in itself.

However, axonometry is successfully used by a new wave of architects with a completely opposite approach (Fala Atelier, OFFICE Kersten Geers David Van Severen, LCLA Office, Dogma, MOS Architects among others) (Figure 10). After the boom of computer graphic rendered images, architectural representation is now looking for something less realistic but more evocative. As Sam Jacob stated in the title of his essay, 'Architecture Enters the Age of Post-Digital Drawing'. Since renderings are too realistic, "position us within a predetermined idea of space, an array of preprogrammed presets rather than an ambiguous possibility that can be constructed ... Yet it's exactly this fait accompli idea of reality that the return of the drawing seems to challenge" [20] (Sam Jacob).

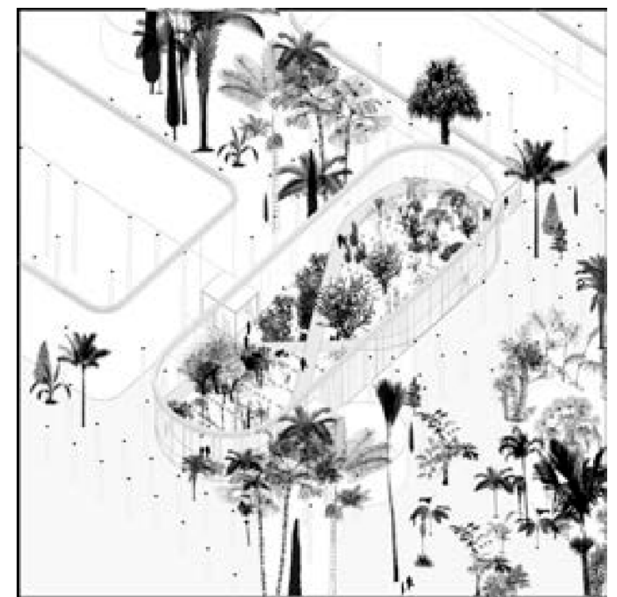

(a)

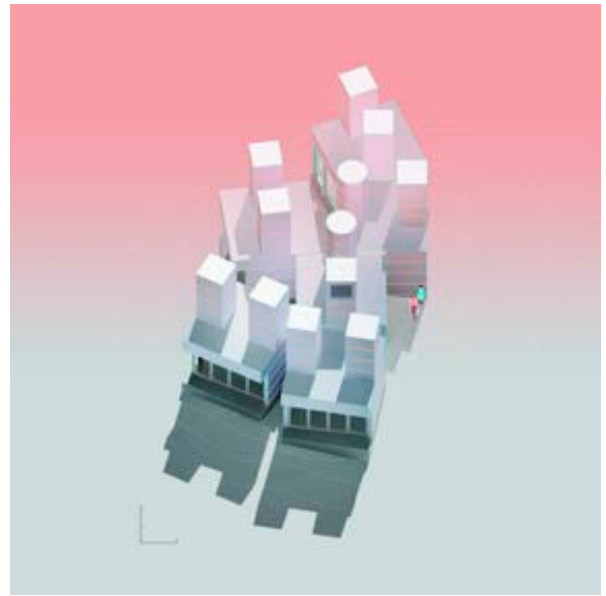

(b)

Figure 10. (a) LCLA Office, Tropicarium Bogota, 2014; (b) MOS Architects, House No. 9, 2015. 
Instead of impressing the observer with an imitation of reality (a fake frozen image), the drawings by those architects denote their abstraction, they do not hide their artificiality but, even though they are digitally produced, still embody the value of their hand-drawn ancestors.

Especially when it is zoomed in, the digital axonometric drawing on a screen works like the Chinese landscape painting: navigating the picture is like wandering through space, lingering on the details. Once again, as in Wang Hui's handscrolls, non-central projection brings coherence among all the scenes in the picture.

\section{Visions}

If "any picture is an account of looking at something" [21] (Hockney \& G., p. 8), this account is even more meaningful if the subject of the image does not exist. The image is then the epiphany of the thinking process itself. More than the representation of something that exists, that is real, project drawings are not only accounts of a look, but accounts of a vision.

As testifed by its use throughout art history, axonometry is associated with technicality and feasibility; it embodies the aesthetics of the design thinking, the visualization of the project vision.

Axonometry stands both for concreteness - as a mathematical depiction of a subject-as well for abstraction-as a detachment from the habitual perception. Axonometry is the scientifc reproduction of a mental space, solid-state imagination.

"When we imagine a thing, or strive to visualize it in the mind or memory, we do it in this way, without the distortions of ordinary perspective. Isometric perspective is therefore more intellectual, archetypal, it more truly renders the mental image - the thing seen by the mind's eye" [22] (Bragdon, p. 8).

Axonometry is then the account of the thought over the space, not just the reproduction of it.

Conflicts of Interest: The author declare no conflict of interest.

\section{References}

1. Hockney, D.; Gayford, M. A History of Pictures: From the Cave to the Computer Screen; Thames \& Hudson: London, UK, 2016; p. 20, ISBN-13 9781419722752; ISBN-10 1419722751.

2. Cosgrove, D. Carto-City. In Else/Where: Mapping-New Cartographies of Networks and Territories; Janet Abrams, J., Hall, P., Eds.; University of Minnesota Design Institute: Minneapolis, Minnesota, 2006; p. 156, ISBN-13 9780972969628; ISBN-10 0972969624.

3. Centro Carlo Scarpa at the State Archive, Treviso. Available online: www.carloscarpa.it (accessed on 12 September 2017).

4. Gellner, E.; Mancuso, F. Carlo Scarpa e Edoardo Gellner. La Chiesa di Corte di Cadore; Electa: Milan, Italy, 2000; p. 38, ISBN-13 9788843576555; ISBN-10 8843576550.

5. Castelvecchio Museum Archive, Verona. Available online: www.archiviocarloscarpa.it (accessed on 12 September 2017).

6. Scolari, M. Oblique Drawing: A History of Anti-Perspective; MIT Press: Cambridge, MA, USA, 2012; p. 1, ISBN-13 9780262527613; ISBN-10 0262527618.

7. Scolari, M. Oblique Drawing: A History of Anti-Perspective; MIT Press: Cambridge, MA, USA, 2012; p. 3, ISBN-13 9780262527613; ISBN-10 0262527618.

8. Hockney, D.; Gayford, M. A History of Pictures: From the Cave to the Computer Screen; Thames \& Hudson: London, UK, 2016; p. 88, ISBN-13 9781419722752; ISBN-10 1419722751.

9. Hockney, D.; Gayford, M. A History of Pictures: From the Cave to the Computer Screen; Thames \& Hudson: London, UK, 2016; p. 89, ISBN-13 9781419722752; ISBN-10 1419722751.

10. Rowley, G. Principles of Chinese Painting; Princeton University Press, NJ, USA, 1947; pp. 61-63, ISBN-13 9780691003009; ISBN-10 0691003009.

11. Hearn, M.K. Landscapes Clear and Radiant: The Art of Wang Hui (1632-1717); Yale University Press: New Haven, CT, USA, 2008; p. 178, ISBN-13 9780300200041; ISBN-10 0300200048. 
12. In addition to Hockney (op. cit.) and Scolari (op. cit) it is due to mention:

Panofski, E. Perspective as Symbolic Form; Zone Books, MIT Press: Cambridge, MA, USA, 1996; ISBN-13 9780942299533; ISBN-10 0942299531.

Perez-Gomez, A.; Pelletier, L. Architectural Representation and the Perspective Hinge; MIT Press: Cambridge, MA, USA, 1997; ISBN-13 9780262661133; ISBN-10 0262661136.

13. Bois, Y.A. Metamorphosis of axonometry. Daidalos 1981, 1, 57.

14. Bois, Y.A. Metamorphosis of axonometry. Daidalos 1981, 1, 46.

15. Giovanni Battista Belluzzi, quoted in Scolari, M. Oblique Drawing: A History of Anti-Perspective; MIT Press: Cambridge, MA, USA, 2012; p. 9, ISBN-13 9780262527613; ISBN-10 0262527618.

16. Choisy, A. L'art the Bâtir Chez le Romains; Ducher et C.ie, Paris, France, 1873; notes to the planches.

17. Bois, Y.A. Metamorphosis of axonometry. Daidalos 1981, 1, 42.

18. Frampton, K. Modern Architecture: A Critical History, 3rd ed.; Thames and Hudson: London, UK, 1992; pp. 311-312, ISBN-13 9780500202579; ISBN-10 0500202575.

19. Riley, T. The Changing of the Avant-Garde: Visionary Architectural Drawings from the Howard Gilman Collection; The Museum of Modern Art: New York, NY, USA, 2002; p. 122, ISBN-13 9780870700040; ISBN-10 0870700049.

20. Jacob, S. Architecture Enters the Age of Post-Digital Drawing. Metropolis 21 March 2017. Available online: http://www.metropolismag.com/architecture/architecture-enters-age-post-digital-drawing (accessed on 12 September 2017).

21. Hockney, D.; Gayford, M. A History of Pictures: From the Cave to the Computer Screen; Thames \& Hudson: London, UK, 2016; p. 8, ISBN-13 9781419722752; ISBN-10 1419722751.

22. Bragdon, C.F. The Frozen Fountain: Being Essays on Architecture and the Art of Design in Space; Alfred A. Knopf: New York, NY, USA, 1932; p. 8, ISBN-13 9781199797919; ISBN-10 119979791X.

(C) 2017 by the authors. Licensee MDPI, Basel, Switzerland. This article is an open access article distributed under the terms and conditions of the Creative Commons Attribution (CC BY) license (http://creativecommons.org/licenses/by/4.0/). 